\section{TRUMP: TEACHING IN A TIME OF CHANGE}

\section{Robert Smith, Coventry University, United Kingdom}

\section{DOI: $10.1017 / S_{1049096519001999}$}

Major political change may be fascinating to study, but it can be disconcerting to live through. For almost 80 years, Britain has maintained a close relationship with the United States in global politics. This "special relationship" may be, as Hill $(2019,129)$ describes it, a "cliché"; however, as with similar interstate alliances, it is one that has enabled "institutional complexity and bureaucratic inter-penetration." This does not mean that the history of the relationship has been smooth or that the leaders of the two nations have always been close. However, the linkage between the two nations on matters of security and intelligence, trade, and shared diplomatic outlook has meant that the relationship endures even when presidents and prime ministers may diverge. In this context, a disruptive president may cause problems, but the institutions and bureaucracy will persist and the special relationship will be revived in time to the benefit of both sides.

Donald Trump is a disruptive president. He first intervened in my teaching of US foreign policy as the element sent to disturb the consensus on American global leadership. When discussing the notion of grand strategies in US foreign policy, it is customary to refer to the possibility of neo-isolationism (Dueck 2006; Posen and Ross 1996). It is equally customary to dismiss this notion as highly unlikely. However, as the 2016 presidential election campaign unfolded, it became necessary to realize that assumptions about grand strategies, the liberal international order, and global trade that appeared settled and unchanged irrespective of which individual or party was in the White House now may be challenged. At that point, Trump was a disruptive innovation sent to undermine existing structures and beliefs. As such, he acted as a useful teaching tool, a counterpoint to consensus as a way to explore foreign-policy assumptions.

The initial impact of Trump among the student cohort was amplified by his presence on social media. It was not necessary to be supportive of the message to be drawn into the spectacle. Although not a gifted orator, Trump had proved himself to be an effective communicator with his mastering of the Twitter platform. With $82 \%$ of young people in Britain favoring the internet as their primary news platform (Ofcom 2018, 2), Trump was accessible, providing an ongoing commentary on his campaign and then his presidency and his disputes with media, personalities, and fellow global leaders. In Britain, this Twitter activity probably reached its height when, in November 2017, Trump retweeted material posted by the far-right anti-Muslim group, Britain First. The retweets caused great controversy and brought a rare public rebuke from the spokesperson of the British Prime Minister (BBC News 2017). Students could choose to be inspired, enraged, or even entertained by Trump's Twitter output, but it was difficult for them to ignore it. Trump had refashioned the bully pulpit for the digital age.

Thus, the initial phase of the Trump era challenged our ideas about American power and our understanding of how leaders should communicate and act. Trump's political rise coincided with Britain's own period of introspection: following a referendum in June 2016, it voted to leave the European Union. In Britain, both Brexit and Trump have proved divisive. Given these divisions, what is the responsibility of teachers? Writing about the difficulties inherent when teaching students in Britain about Brexit, Johns (2017) returned to a consistent theme of teaching: objectivity.
Johns argued that there are three factors that inhibit the pursuit of objectivity. First, lecturers' teaching is shaped by their assumptions; pure neutrality is not possible. Second, when these assumptions are shared by a community, they are not questioned. Third, individuals "blur the distinction" between what they believe and what they want to believe. To illustrate the problem, Johns (2017) turned to the US president: imagine the dilemma of "trying to form and to teach objective assessments of the Trump presidency separate from their subjective horror at its existence and conduct."

To resolve this dilemma, a possible solution is to take Trump out of Trumpism. For teachers and students of Trump, it is necessary to turn off Twitter. The president's social media feed is distracting, disrupting, and relentless. Therefore, it may be better to step back from the daily controversies to consider the broad themes of policy. As much as the actions of President Trump as an individual may repel, the themes of his foreign policy represent a realist recalibration after the post-Cold War liberalist ascendency (Schweller 2018). Certain policy strands are not new: American primacy, distrust of international institutions, and skepticism about the science of climate change have been persistent themes in Republican thinking for two decades or more. Concern that NATO members are not contributing to the collective security of Europe and that American troops should be removed from the Middle East echo the views of President Obama. That these policies have been wrapped up with a resurgent nativism is different. However, to ascertain these broader themes, it is necessary to advise students to step away from the daily distractions.

Therefore, teaching politics and international relations in a time of change leads us back to the basics of good critical thinking: seeking an objective analysis, recognizing our own biases, and highlighting both what is new and what is familiar. Through this approach, we aim to provide our students with the skills needed to engage with a changing world.

\section{REFERENCES}

BBC News. 2017. "Donald Trump Retweets Far-Right Group's Anti-Muslim Videos.” November 29. Available at www.bbc.co.uk/news/world-us-canada-42166663. Accessed May 31, 2019

Dueck, Colin. 2006. Reluctant Crusaders: Power, Culture, and Change in American Grand Strategy. Princeton, NJ: Princeton University Press.

Hill, Christopher. 2019. The Future of British Foreign Policy: Security and Diplomacy in a World after Brexit. Cambridge: Polity Press.

Johns, Rob. 2017. “How to Make Sure Your Lectures Aren't Too Anti-Brexit.” October 31 Available at www.timeshighereducation.com/blog. Accessed May 31, 2019.

Ofcom. 2018. "News Consumption in the UK: 2018." Available at www.ofcom.org. uk/_data/assets/pdf_file/o024/116529/news-consumption-2018.pdf. Accessed May 31, 2019.

Posen, Barry R., and Andrew L. Ross. 1996. "Competing Visions for U.S. Grand Strategy." International Security 21 (3): 5-53.

Schweller, Randall. 2018. "Three Cheers for Trump's Foreign Policy: What the Establishment Misses.” Foreign Affairs 97 (5): 133-43

\section{KOREAN-US POLITICAL PARALLELS AND THE TRUMP} PRESIDENCY

\section{Jin Min Chung, Myong Ji University, Korea}

\section{DOI: $10.1017 / S_{1049096519001975}$}

As the Trump administration has emphasized the primacy of national interests under its "America First" banner, particularly in the areas of trade deficit with South Korea and the cost of keeping US troops there, Korea and the United States have 
faced many challenges and still have unsolved problems. More important, however, the United States has long been a model for Korean presidential democracy. In fact, the United States and South Korea present a substantial number of parallels with respect to their constitutional structures, electoral systems, party systems, and political situations. Among other parallels, both democracies have presidential systems. Despite disparities such as the terms of office and the rules of elections, there is no doubt that the presidents in South Korea and the United States are leading political figures, as well as the only public officials elected by the entire electorate. In addition to its presidential system, South Korea parallels the United States in its long-standing use of a single-member plurality system for legislative elections. ${ }^{1}$

An electoral system often is viewed as the primary institutional determinant of a legislative party system. A single-member plurality system has the effect of putting a higher threshold of exclusion to the advantage of large parties or manufacturing majorities, thereby facilitating the two-party system in both South Korea and the United States. In addition, the candidate-selection procedure in major Korean political parties has evolved in a more democratic direction, departing from top-down candidate selection in the past. In adopting the bottom-up method of candidate selection, major Korean parties have opened up the selection process of candidates-most importantly presidential candidates-not only to party members but also to ordinary voters as in the US primary system because most Korean political parties are lacking members who voluntarily joined the party.2

The two major parties in South Korea-the liberal Democratic Party and the conservative Liberty Korea Party-are not only dominant but also increasingly polarized in recent years. The upward trend in party polarization in South Korea is similar to US party polarization, which has developed since the Reagan Era of the $198 \mathrm{os}$ and further deepened in the twenty-first century, particularly after the 2008 election of President Obama and the emergence of the and political parties. Political parties are increasingly influenced by party activists focusing on their ideological issues rather than ordinary voters' pressing issues of daily life. Voters frustrated with establishment parties and politicians have become more vulnerable to the populist mobilization by "outsider" politicians, who often make use of inflammatory and provocative rhetoric. Korean students in American politics classes tend to view the emergence of the populist Trump presidency in part as a result of a growing disconnect between American voters and the political establishment. Given the Korean-US parallels, they also express their concern about a possible emergence of Korean populist politicians who are not accountable for their actions and who try to break or bend the law to solve political problems.

Another worrisome parallel between the two democracies is the strengthening negative partisanship aggravated by various challenges to the basic parameters of American democracy under the Trump presidency. Korean partisan voters' negative feelings toward the opposing party and its supporters also continue to grow. According to a Gallup Korea poll (March 8, 2019), Democratic Party supporters' dislike of the Liberty Korea Party was $88 \%$, and Liberty Korea Party supporters' dislike of the Democratic Party was $89 \%$. In fact, Korean partisan voters dislike or even hate one another more than they did in the past, thereby further reducing the low level of political tolerance that is a core element underlying the workings of the democratic process. Unfortunately, political tolerance also seems to be suffering under the Trump presidency largely due to emotionally charged party polarization, which was well reflected in the clearly distinct responses of Democrats and Republicans to the redacted Mueller report.

Because of the many parallels of political systems and situations in the United States and South Korea, American politics has set-for better or worse-a type of reference structure for evaluating various aspects of Korean politics and suggesting

\section{Because of the many parallels of political systems and situations in the United States and South Korea, American politics has set-for better or worse-a type of reference structure for evaluating various aspects of Korean politics and suggesting political reforms.}

conservative Tea Party movement. Consequently, there has been a notable increase in party votes in the American Congress; legislators more often support their party on party votes, frequently leading to legislative gridlock as well as executive-legislative confrontations.

These confrontations have been further exacerbated under the Trump presidency, as demonstrated by the longest government shutdown and the unprecedented delay of the State of the Union Address as a result of partisan bickering. The excessive partisan conflict is now greatly undermining governance in America. Likewise, the two major parties in South Korea are no less polarized than their US counterparts. In Korea's National Assembly, party cohesiveness of the two major parties also is very high, frequently resulting in fierce confrontations within the increasingly polarized legislature and undermining governance. This was evident in the recent three-month-long legislative deadlock triggered by the ruling Democratic Party's move to fast-track key reform bills.

Polarized party politics in South Korea and the United States typically leads to growing disconnect between ordinary voters political reforms. Moreover, a long history and accumulated experiences of American democracy with similar political systems and situations continue to provide ample precedents related to the workings of presidentialism and the challenges facing Korean presidential democracy, such as executive-legislative tensions embedded in the constitutional structure of power separation based on dual legitimacy.

\section{NOTES}

1. Although the Korean electoral system combines a plurality system with proportional representation, most National Assembly members (i.e., 253 of 300) are elected in single-seat constituencies.

2. When the major Korean parties adopt a party-primary or closed-primary system restricted to party members as a method of democratizing candidate selection the lack of genuine party members typically leads to unfair primary competition in favor of a contender controlling the party organization or it creates instant party members in large numbers. For this reason, the major Korean parties have combined the party-primary and the open-primary systems, allowing participation of nonmember voters, which often is accompanied or replaced by a public poll. 